\title{
The social movement of street vendors to maintain their business places in Bandung
}

\author{
Gerakan sosial Pedagang Kaki Lima (PKL) untuk mendapatkan tempat \\ usaha di Kota Bandung
}

\author{
Rina Hermawati, Oekan S. Abdoellah, Budhi Gunawan, \& Selly Riawanti \\ Department of Anthropology, Faculty of Social and Political Sciences, Universitas Padjajaran \\ Address: Jalan Raya Bandung-Sumedang Km 21 Jatinangor, West Java 45363 \\ E-mail: r.hermawati@unpad.ac.id
}

\begin{abstract}
This study views street vendors as public issues which are related to the conflict over public spaces between the government and the street vendors. The conflict was derived from differences in the interpretation and meaning of public spaces. The government has visions of order in the city and tries to control the street vendor in public place. However, the street vendors interpret public place as a strategic place to conduct their business and try to defend their existence in it. The differences in interpretation encouraged the birth of street vendor movement in Bandung. This research employed social movement concept to describes how street vendors try to construct their identities, build up the strength of their organization/association, frame and disseminate issues, and establish some coalitions. It used a qualitative method with case study research by attaining some cases of street vendors in Bandung and observing their news through newspaper and online media between 20152016, as well as conducting some interviews with key informants. The data collected through participative observation, thorough interview with street vendors, municipal government, street vendors' organizations/ associations, and focus group discussion. This research showed that the process of identity construction is carried out informally through kinship system. Furthermore, the street vendors built their movement based on issues of unjust policy which is supported by right to seek livelihood, marginalization issue, and limited access to formal economic sectors. These issues become their justification to maintain their business in public places and their efforts to go against government interpretation of public places which become their foundation to formulate policies about street vendors. Lastly, to strengthen their bargaining position against the government, they establish three types of coalition; political coalition, political-economy coalition, and economy coalition.
\end{abstract}

Keywords: street vendor; public place; social movement

\begin{abstract}
Abstrak
Penelitian ini memandang persoalan PKL sebagai isu publik yang berkenaan dengan konflik ruang antara pemerintah dan PKL. Konflik ruang tersebut tidak terlepas dari perbedaan interpretasi dan makna atas tempat publik. Pemerintah dengan visinya mengenai kebersihan, keindahan dan ketertiban kota berupaya mengendalikan keberadaan PKL pada tempat publik, sedangkan PKL dengan interpretasinya mengenai tempat strategis yang banyak dilalui kerumunan berupaya mempertahankan keberadaannya pada tempat publik. Perbedaan interpretasi atas tempat inilah yang mendorong lahirnya gerakan PKL di Kota Bandung. Dengan menggunakan konsep gerakan sosial, artikel ini bertujuan untuk menggambarkan bagaimana PKL membangun identitas, membangun kekuatan organisasi/paguyuban, membingkai dan menyebarluaskan isu, serta membangun koalisi. Metode yang digunakan adalah metode kualitatif dengan strategi penelitian studi kasus. Untuk mendapatkan kasus tentang PKL di Kota Bandung, peneliti melakukan pengamatan terhadap pemberitaan PKL di Kota Bandung melalui media cetak dan media online selama tahun 2015-2016 dan wawancara terhadap informan kunci. Teknik pengumpulan data berupa observasi partisipasi, wawancara mendalam kepada PKL, pemerintah kota dan paguyuban/asosiasi PKL serta Fokus Grup Diskusi dengan PKL dan asosiasi/paguyuban PKL. Hasil penelitian menunjukkan bahwa proses pembentukan identitas dilakukan dengan menggunakan cara-cara yang bersifat informal dan kekeluargaan. Sedangkan isu yang dibangun PKL berkaitan dengan isu kebijakan yang tidak adil didukung oleh isu atas hak atas pekerjaan, marginalisasi dan keterbatasan akses pada ekonomi formal. Isu-isu tersebut menjadi dasar pembenaran bagi keberadaan PKL pada tempat publik sekaligus upaya PKL untuk melawan pemaknaan tempat publik sebagaimana diinterpretasikan pemerintah dalam kebijakan tentang PKL. Untuk memperkuat daya tawarnya terhadap pemerintah kota, PKL melakukan koalisi dengan membentuk tiga jenis koalisi yaitu koalisi politik, koalisi ekonomi-politik dan koalisi ekonomi.
\end{abstract}

Kata kunci: gerakan sosial; pedagang kaki lima; tempat publik 


\section{Introduction}

Different interpretation and meaning of public spaces between municipal government and street vendors have generated conflict over those spaces. Municipal government, with its visions on city hygiene, attractiveness, and order, has tried to regulate street vendors in public spaces. On the contrary, street vendors with their interpretation of public spaces as a strategic place to trade have attempted to maintain their presence in those spaces.

Conflict over public spaces causes whatever policies taken by the municipal government, both repressive (strict control and relocation) and persuasive (organizing and aiding), has never fully resolved any issues related to street vendors. Despite repeatedly being reorganized, relocated, and controlled, street vendors keep burgeoning and reappearing, even growing more and more.

Various studies concluded that the failure in solving this problem is caused by street vendors' resistance (Aisyah 2012, Alisjahbana 2006, Gibbings 2011, Hanser 2016, Hermanto 2011, Mustafa 2008, Siswono 2009, Turner \& Schoenberger 2012). These studies basically showed how the street vendors carry out their resistance movement, both covertly and openly, through negotiation and accommodation to sustain their business. Resistance, negotiation, and accommodation work in a flow and unity; though at times it is separated, it is reunited again as power relations in the context of administering public spaces. This article discusses the efforts of street vendors in fighting for their business in public places using social movements perspective. This study is important to view how the dynamics of street vendors movement are, how the street vendors portray the issues, and how they choose the form of resistance in accordance with policy contexts and parties they face.

In examining street vendor movement, the authors employ two main concepts in social movement, namely framing and consolidation. Framing refers to conscious, strategic attempts of a group of people in order to shape common understanding about the world and themselves which validate and drive some collective actions (Snow et al. 1980). At this stage, a leader establishes a 'frame' to mobilize his/her groups by creating some issues about injustice and establishing emotional ties. Hence, during the framing process, there is an attempt to construct issue and identity. The constructed identity and ideas are dynamics, depending on the message and meanings intended to convey and to whom they shall be conveyed. Related to street vendors' movement, framing signifies street vendors' attempts to formulate and curve their issues as social problems. They also construct street vendors' feeling and identification as individuals to act collectively and formulate what kind of collective action they shall take. Framing dynamically depends on the policy context and parties the street vendors may face; while consolidation refers to internal and external unification of forces. Internal consolidation is conducted by unifying street vendors under one foundation/organization and establishing strong organization and good resources management, both human and financial resources. In order to increase its force, street vendors' organization can conduct external consolidation by garnering sympathy/support from various parties and establishing some networks with government, legislative institution, non-governmental organizations, and other parties who may help street vendors' presence in public places.

\section{Research Method}

This research employed qualitative strategy with study case method. In order to obtain a specific case on street vendors in Bandung, the authors conducted some observations on street vendors-related news through some online media between 2014 and 2016. Based on various news, we obtained some interesting news in Bandung, namely street vendors' relocation at X and Z street in Sumurbandung; street vendors' reorganization at Y Street, Andir; street vendors' relocation at A street in Balong Gede; and street vendors' relocation at B street, Coblong.

In those locations, the authors collected data by gathering participation of street vendors, engaging in some interviews and taking documentation. Observations were made to directly observe the street vendors' sales activities, circumstances and interactions they do, and strategies they develop to fight for 
their business place. In this participative observation activity, the authors carefully observed what they did, when they did it, with whom, and under what circumstance; then posed some questions about it.

Some interviews were conducted with street vendors, management of street vendors associations/ community, Public Order Enforcers (hereafter, Satpol PP - a municipal police unit), Department of Cooperative for Small-Medium Business and Trade Industry (hereafter, KUKM \& Indag Department) and Regional Development Planning Agency (hereafter, Bappeda). Broadly speaking, we conducted the interviews on some topics about socioeconomic characteristics of street vendors, street vendors' attitudes towards government policies (control, relocation, reorganization, and training), and street vendors' response toward these policies.

A Focus Group Discussion (FGD) was conducted with ten street vendors from each location and five people administered the PKL associations/community separately in order to sharpen the data that had been obtained in the interview. FGDs with street vendors were conducted to find out how they choose and maintain a place to sell; while FGDs with the associations/ communities were conducted to find out how they were engaged in fighting for the interests of street vendors for their business place. While the documentation materials were mainly related street vendors' characteristics and distribution and organizations, municipal government policies to handle street vendors, and street vendors' strategies in dealing with the municipal government policies. These documents were obtained from Satpol PP, KUKM \& Indag Department, Bappeda, street vendors' associations/foundations, internet, blogs, photos, videos and other literature.

\section{Results and Discussions}

Growth and development of social movement are influenced by three inseparable factors, namely political opportunities, mobilization structures, and framing processes (McAdam et al. 1996). Political opportunities and mobilization structure are essential factors to incite social movement; however, both are insufficient without the third factor: framing. Political opportunity concept explains that social movement is frequently triggered by significant changes in political structure; hence, dimmed social movement is also frequently prompted by some shifts in the structure. In other words, political structure can either accelerate or conclude collective actions, but it is insufficient to trigger it to happen without being supported by mobilization structure which is deeply rooted in previously established social network. Through the network, masses and sympathizers were recruited and mobilized. In order to mobilize the mass, the actors of social movement should frame their planned actions through slogans and simple language in order to tap into the mass' sentiments. Framing is an essential art to communicate some messages to move and ignite support and participation.

In order to establish this collective action, at least three elements are needed, namely justifying over the collective action, distinguishing friends and foe, and clarifying how are "we" different from "them." Within this framework, the actors of the movement attempt to construct street vendors' identity as extended families formulate issues to counter municipal government's policies, and build justification on marginalization issue to attract public sympathy. To put it simply, framing in street vendor movement is summarized in Table 1.

Table 1.

Framing in Street Vendors Movement

\begin{tabular}{ll}
\hline Constructing identities & - Establishing internal unity (street vendors as extended family). \\
& - Drawing a line on friends and foes. \\
\hline \multirow{3}{*}{ Opposing policy } & - Reorganization policy vs unjust policy. \\
& - Street vendor's reorganization and training policy \\
& vs subtle form of control policy. \\
\hline Garnering support and sympathy & - Marginalization issues. \\
from society members & - Rights to seek livelihood. \\
\hline
\end{tabular}




\section{Framing unity issues among the street vendors}

Unifying process between street vendors is constructed by shaping their identities as one extended family. The process of idea construction has begun from their habits to converse and chatter amidst or after their business hours. During their conversation, they usually discuss various issues, from personal to economy and politics issue, including some situations considered threatening their business sustainability. Furthermore, relocation and control policies of the government instill feeling of unity and affinity among them.

Such identities are nurtured and developed by street vendors' organizations. Using amicable means, these organizations implant some habits to build personal relationship with their members, including with their family members. The street vendors and their families frequently meet each other in some informal events, including weekly gathering, social gathering, motorbike touring, going to some celebration together, and visiting other members who are sick or encounter unfortunate incident.

In addition, organizations attempt to strengthen street vendors' identities as one family. When street vendors are being subjected to government's control policy, they conduct some advocacy and mentoring activities. When street vendors experience problems in fulfilling their daily needs, like in health and education, they also do not hesitate to provide some assistances. The form of assistance is by helping the street vendors to take care of administration process for Certificate of Financial Inadequacy (SKTM) and to request some cost reduction to hospitals and schools. Organizations also act as mediators when some street vendors have some disagreement with each other or experience some family problems. Disagreement between street vendors is usually caused by price differences or some offensive utterances. Those disagreements are usually resolved by the organization amicably. Likewise, for some street vendors who encounter domestic problems, the organizations sometimes provide some consultations and advices to solve the problems.

Besides personal and social problems, street vendors are also united by political issues, especially related to leadership at national and local levels. During election periods (presidential, governor, or major elections), the organizations usually require their members to vote certain candidates and sometimes declare their choices publicly.

Due to the tightly-knit relationship patterns, the street vendors feel that they are really a part of an extended family and their level of dependence with organization is extremely high. Moreover, the formation of identity is strongly supported by some traditional Sundanese jargons, namely ' $K u d u$ sapapait samamanis, sabagja cilaka' and 'Silih Asah, Silih Asih dan Silih Asuh'. The jargons are adhered by the street vendors to care and love other fellow street vendors.

\section{Case 1: Establishing unity}

In dealing with control and relocation policies, the street vendors at the $\mathrm{X}$ street in Sumurbandung and Y street in Andir have put up individual and spontaneous resistance by gossiping, pretending to obey, and playing hide-and-seek (disappearing during the control attempt by Satpol PP and reconducting business when they feel safe). Although such resistance attempts can maintain their business, but they are easily breakable. Under uncertain conditions, the street vendors form a unity by establishing an organization, either in the form of cooperative or foundation. This process is supported by some leaders which emerge among the street vendors, mostly senior and influential street vendors. The leaders then foster the unity between the members through a series of informal activities, such as routine gathering and social gathering, venting about personal problem, holding some discussions, helping other street vendors who encounter problem in accessing health care and education, and many others.

Identity construction is considered successful when the street vendors perceived themselves as one extended family, signaling that identity as a "we" has been established. However, not all street vendors' organizations can reach this stage, because some organizations split up due to some internal conflicts. 
The conflict is triggered by mistrust of some members toward the management or committee members. Accusation of membership fee embezzlement by the management or disagreement over certain issues are usually powerful enough to trigger division among them. Such conditions may be accelerated by the management's incapability to provide "safety" for the street vendors. This kind of division is usually resolved by changing the management or establishing a new organization for the opposition parties.

\section{Case 2: Internal conflicts among street vendors}

Street vendors at X street in Sumurbandung established Cooperative A which later affiliated with a civic organization in Bandung and required its members to pay membership fee of IDR 300,000 per month in exchange of safety in conducting business. Nonetheless, in reality, they still have to be relocated and reorganized, so they start questioning the membership fee, along with the functions of Cooperative A and civic organization. The situation is worsened by the cooperative's idea to suggest street vendor's relocation to Mall $\mathrm{Z}$ which is still located around $\mathrm{X}$ street. From the point of views of the street vendors, this relocation will "assassinate" their business. Moreover, previously they were relocated once to $G$ street, but it failed due to lack of consumers. Hence, when the government formulates the relocation policy to the Mall $\mathrm{Z}$ and the cooperative accepts it, some street vendors decide to quit the cooperative and establish a new organization.

Other problems are related to the relationship between street vendors' organizations. The diversity of street vendor affiliations in numerous organizations has caused the unity constructed between the street vendors to be limited within their respective organizational spheres. Even if there is cooperation between organizations, it incidentally occurs when they face similar problems, like when their "territory" is exposed to reorganization problem. Hence, a more permanent unity does not exist. On the contrary, it is not uncommon for the street vendors to compete in a "territorial conquest" in order to enlarge the organizations. Although it never caused any open conflicts between the organizations, the competition usually causes a "cold war" between them.

The second identity construction process involves identification between friends and foes. Identifying common enemy is considerably easy. The street vendors' common experience in reorganization and relocation have made them commonly "allergic" toward the municipal government. Such experience is supported by the knowledge spread by organizations about who street vendors are, who government is, and why are they on the opposite side. The street vendors' organizations personify municipal government with the mayor, so they and the street vendors often regard the mayor as their enemy and the most frequent party who stands opposite of them. Nonetheless, sometimes the organizations portray a dual-faced politics with the government. On the one hand, they consider government as their enemy; on the other hand, they conduct some informal approaches to obtain financial assistance.

Besides the municipal government, some organizations have other enemies, namely those considered to be in 'higher class' and tend to 'disrupt' their business, or the so-called 'entrepreneur street vendor'. They refer to those with huge capital, but conducting their business like the common street vendors. For instance, store's and factory's owners who peddle their goods in the sidewalks, or 'modern street vendors' who use their cars to sell luxurious goods.

Meanwhile, 'friends' refer to those helping street vendors' cause, namely mass media, university students, social activists, non-profit organization, civic organization, and public. While political parties and legislative institutions, though formally play an important role in delivering the street vendors' aspirations, the street vendors have no urgency to establish a friendship with them. It might be caused by political parties' tendency to approach them only to obtain electoral votes and the street vendors also consider political parties being not attentive with their aspirations.

\section{Opposing government policies regarding street vendors}

In order to undermine government policies regarding street vendors, the street vendors construct an issue about unjust policies. They also argue that reorganizing policy is the soft form of strict 
control enforcement; that the policy implementation is inconsistent; and that the law enforcers have weak mentality. The street vendors construct unjust policy as the core counter argument to the government policy to control and relocate them. Based on their point of views, such policies carry no solutions and do not favor the interest of "commoners." Their bad impression about reorganization and relocation policies is worsened by its implementation, of which they considered as "selective cutting' and 'hot money' earning for the authorities.

Those issues are constructed during some dialogues between the street vendors, protests, and argument with the authorities. These following statements reflect the arguments uttered by the street vendors when the municipal government plans to relocate them from $\mathrm{X}$ street to $\mathrm{Y}$ street:

\footnotetext{
"Evicting us from the streets is easy, but the harder task is...what's next? If the government actually cares about public welfare.... There are many street vendors, homeless people, and beggars due to government's fault. It isn't our choice... if there's more decent life, no one wants to be a street vendor" (Budi, a street vendor at X street).

"If the street vendors are being controlled, it is similar to assassinate small business. Not only street vendors, but also small-medium enterprises. [Because] the street vendors are the $60 \%$ outlets of small-medium enterprises. So, [I think] reorganization gives no solution" (Agus, the head of street vendors association).

"Reorganization is supposed to be the last resorts. Currently all spots are being reorganized, like Tegallega and Gasibu, but no further solution. It shows that the government is incapable, doesn't it? If the authorities have 'pro-commoners' character, not pro-entrepreneur, then [they] should put our welfare first" (Ilham, a street vendor at X street).
}

Moreover, the street vendors also question reorganization policies which are considered selective cutting. Ilham, the street vendor at X street, retold his story of being hunted by Satpol PP. He found it puzzling why strict control attempt is often conducted around his area, while other areas are relatively secure. He suspected that it is caused by different amount of money being given to the Satpol PP officers as bribery. Hence, he concluded that such policy is too far-fetched due to its inconsistent implementation.

Meanwhile, Budi, the street vendor at $\mathrm{X}$ street, has different suspicion. In his opinion, at the implementation level, the street vendors and Satpol PP officers feel like close friends who frequently throw some jokes to each other.

\footnotetext{
"Geus lah maneh teu nanaon jualan didieu"

"(It is okay to sell here) but give us money. This is not right, isn't it?"
}

He further suspected that reorganization and control policies are merely Satpol PP's attempts to gain more 'ransom' from the street vendors' raided merchandise. Similar to reorganization and control policy, relocation policy also garners negative responses from the street vendors. Vehement resistance frequently occurs in each relocation effort. Even though the street vendors initially obey the government, most of them will return to the original place. For instance, relocation from seven locations along Gedebage region, relocation from Sudirman Street to Ciroyom Market, and many others. The street vendors' attempt to return to their original places is justified by declining sales turnover, decreasing number of customers, and difficulties in accessing the new location. Based on their point of view, the failure of relocation policy is caused by government's inability to understand the street vendors' issues; hence, they have no "recipes" to solve their problems. For them, the government is unable to understand the street vendors' characters, goods, and customers.

\section{Case 3: Failure of relocation at $Y$ street}

The government once decided to relocate the street vendors from $\mathrm{Y}$ street to Market $\mathrm{C}$ and obliged them to pay a down payment of IDR 2.5 million and monthly installments of IDR 620,000. However, 
the street vendors only conducted business in Market $\mathrm{C}$ for a few months, because the market was quieter as more street vendors were still selling along the street and the buyers preferred to buy from them. Lack of buyers at the Market $\mathrm{C}$ caused the street vendors to return to the street. At that time, they tried to form a unity and opposed the relocation policy by conducting a protest which was assisted by some NGOs; however, it did not produce optimal results, because the government did not offer any solutions to the problems. Finally, from 495 street vendors who had been relocated to Market $\mathrm{C}$, only three street vendors decided to stay in Market $\mathrm{C}$, while the rest decided to return to Y street.

Regional Regulation No. 4 of 2011 concerning the Arrangement and Training of the Street Vendors has changed policy paradigm on the street vendors, from strict control attempt to rearrangement and training. Even though the regulation is considered more accommodating to the street vendors, but they still think that it has many weaknesses. The most basic weakness is the determination of street vendor zones, which are not decided based on compromise between street vendors and the government. Another weakness is related to the government's unpreparedness in implementing empowerment programs for the street vendors.

Implementation of the regional regulation still meets various obstacles. For street vendors, the rearrangement efforts carried out by the government are only a soft form of controlling policies. It is indicated by the reorganization occurred in the red zone, which was not followed by the readiness of relocation sites. Even if there is a relocation site, it is not strategically located (from the street vendors' perspectives). The sites are not crowded with visitors, have no adequate facilities, and sometimes the infrastructure have yet to be built. Moreover, such attempts are not followed by other policies like promotion and empowerment programs. As a result, many street vendors experienced a sharp decline in sales turnover. For street vendors, structuring activities should be carried out by first preparing a place and promotional efforts.

The problems of street vendors' policies are related to two issues. First, the polices do not accommodate the interests of the street vendors. Second, its implementation efforts are insubstantial. In a broader context, this policy issue is directed toward unjust policy and unfavorable toward the poor/weak people.

\section{Policy on street vendors' arrangement from the point of views of street vendors}

Centered around unjust policy, the street vendors demand some solutions from the government, starting from providing them a strategic location to conduct business. Based on the point of view of street vendors' organizations, relocation of street vendors requires special attention toward the goods they sell, either goods that need customers to chase after them, or goods that do not require customers to do so. For the first type, the street vendors are more difficult to be relocated, because they sell food, beverages, and other necessities. This street vendor is usually characterized by utilizing crowded public places. If they are relocated, they should be relocated not farther away from the original place. Therefore, street vendors' organizations encourage the government to regulate $10 \%$ of public places for UMKM in each modern shopping complex located in an area more than 2,000 meter. According to Regional Regulation No. 2 of 2009 on the Management of Traditional and Modern Market, there is a regulation to establish some clusters for street vendors by utilizing vacant buildings, opening new areas with certain zones for street vendors, and reorganizing street vendors without relocating them from the original place. Without relocating them, the government merely needs to reshape and repaint the business place, so that they can turn it into new attraction point of the city. To support space availability for the street vendors, the organizations encourage the requirement for street vendors to have residential card of Bandung city. Meanwhile, for the second type of street vendor, the street vendors can be relocated to any locations as long as it is accessible. This type of street vendors usually sells steels and motorbike's spare parts.

The solution offered by these organizations is directed toward changing the status of street vendors to be a merchant in informal sector. It can be considered as a solution where the street vendors are no longer considered as city problems, so that the government shall consider acknowledging their 
presence. Nonetheless, as the stakeholder in urban planning, the government shall pay attention to the street vendors' characters, their customer targets, and formal sectors or main activities surrounding them. Finally, reorganization of street vendors can succeed if the policy is integrated with the empowerment program for the street vendors. Reorganization is related to finding a suitable place for the street vendors according to their characters; while empowerment is related to promotional activities and capital assistance.

Based on the explanation above, we can conclude that whatever policies taken by the government, they can trigger resistance from the street vendors. When reorganization is conducted, the street vendors shall resist and demand for some spaces to conduct business. When relocation is conducted, they shall resist based on the argument that the new places are not strategically located and nonexistence empowerment program (both business and financial aids). It implies that the issues within street vendors' movement always change according to policy dynamics of the municipal government.

\section{Marginalization issue and right yo seek livehood to garner public support and sympathy}

In order to garner sympathy and support from the public, street vendors' organization center the issue around unjust policy, human rights, and marginalization of street vendors. Human rights issues are related to the right to earn a living or seek livelihood and right to gain employment. Based on the organization's point of view, prohibition on trading for the street vendors contradicts individual rights to seek livelihood and support their families.

In addition, the issue of human rights is usually associated with enforcement and relocation activities which are often carried out through means of intimidation and violence. Some cases that often occur during control activities are destruction of PKL facilities and merchandise, as well as physical clashes between the street vendors and Satpol PP. While marginalization issue is associated with the absence of government policies that favor PKL interests and identification of street vendors as weak and poor groups, contrasted with elite groups (government) and business groups (including modern street vendors).

These issues are spread through discussions, dialogues, and symbols presented during protest and published in mass media or social media. Among the public, these issues are constructed through slogans and symbols presented during some protests. The following slogans were used during resistance against relocation at Merdeka street: "We are colonialized in our own land"; "Red zone 1 million fine, Yellow zone questionable, Green zone is green due to money"; "Bandung, Champion of Miserable Street Vendors"; "Street Vendors = Forgotten Society Member"; "No meaning in beautiful city if its people cannot eat well"; and many others. In order to strengthen such slogans, some theatrical acts are performed using symbols like earplugs, black cloth, coffins, empty pots and kitchen utensils, muddy bodies, and so on. These slogans and symbols represent the messages that the street vendors are marginalized and poor due to the municipal government's unjust policies.

For the mass media, online media, and social media, the leaders of street vendors usually spread the news about reorganization, relocation, organization activities, attitude toward government policies, and solution for their problems. One of the most effective issues to attract public attention is alleged violence which is committed by Satpol PP toward the street vendors. These issues are spread to turn street vendor issues as social issues which garner public sympathy (Figure $1 \&$ Figure 2).

\section{Internal consolidation: Establishing and strengthening street vendors foundations/ organization}

Awareness to establish organizations for street vendors emerge when individual resistance is considered ineffective. This awareness reaches its momentum when a leader among the street vendors appears and attempts to coordinate the street vendors. A leader is usually a senior or a vocal critic against government policies. The leaders become the main agent to determine the groups' structure, objective, and group's activities. These leaders then establish a local community, in the form of either cooperative or formal organization, and determine the structure and management, as 
well as members' rights and obligations and mobilization of the members. These leaders have the rights to determine and collect membership fees, as well as to protect the members from various issues, particularly to ensure their safety in conducting business. If the members consider their safety is threatened, they usually elect another leader who is perceived to be more capable of providing it. On the contrary, if the leaders can ensure the members' safety, he/she will be able to control the management/organization within undetermined period.

Through these foundations/organizations, the street vendors attempt to manage their resources to conduct their common activities. These attempts include supporter mobilization and resource mobilization, which to some extent influences the emergence of elite and public sympathy toward the organizations' cause. It is also known as resource mobilization (Opp 2009). This concept attempts to uncover how the organizations could maximize their resources in order to ignite social changes and achieve their objectives (Edwards \& McCarthy in Snow 2004).

Resources mobilization framework explains about two aspects. First, physical, non-physical, and financial resources possessed by a movement, namely building, money (financial), knowledge, and expertise. Those resources are controllable individually and collectively. Second, mobilization refers to an inseparable process from its actors who attempt to utilize their resources to achieve the organizational objectives.

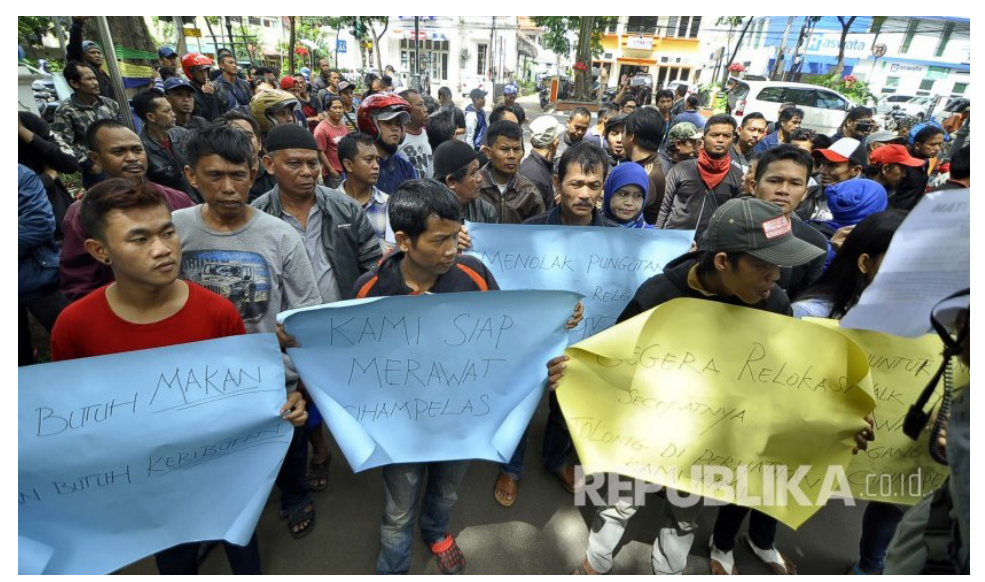

Figure 1.

Marginalization Issue and Right to Seek Livelihood

Source: https://www.republika.co.id/

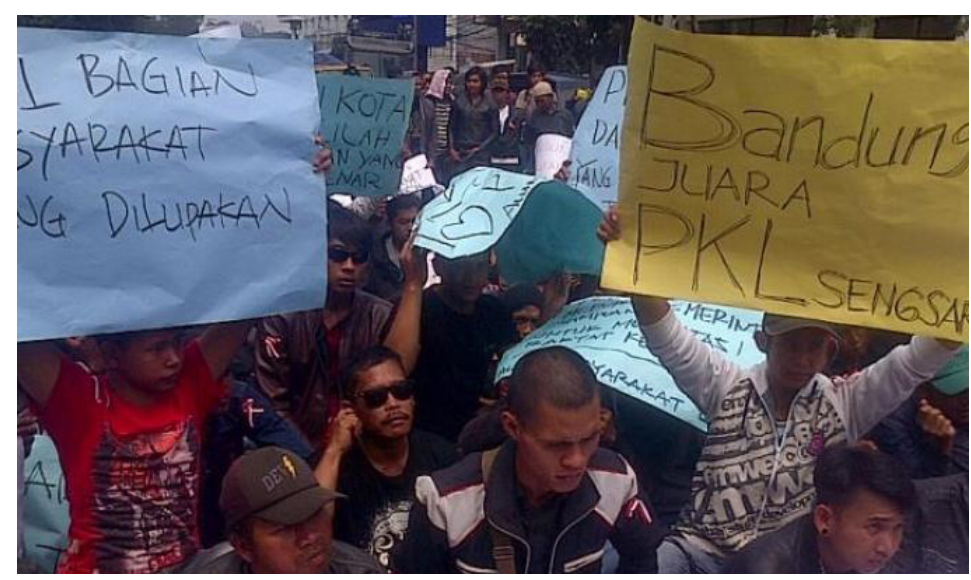

Figure 2.

Marginalization Issue and Right to Seek Livelihood

Source: http://medan.tribunnews.com 


\section{Human resources of organizational movement}

Management of street vendor organization usually consists of non-street vendors and street vendors. They are elected based on word-of-mouth recruitment process, depending on personal relationship or personal suggestion based on organization's work basis. Mechanism of changing committee members is usually conducted every three or five years through an internal deliberation process; though, in fact, the committee members usually resign after they find other activities or are considered problematic by some organization's members.

In order to enhance organizational capabilities, these organizations usually invite some competent experts in their respective fields, such as law experts, economic experts, army personnel, and influential figures within government institutions. Organizational activities generally depend on the committee members. Unfortunately, not all members have enough time for organizational activities. Some members only write their names on papers, without significantly contributing to the organizations. Like the committee members, the members are usually recruited through different means. Some organizations directly approach and offer membership to the street vendors. Some others are approached by the street vendors who express their intention to join. Generally, the street vendors join an organization after facing some pressures from the municipal government. To strengthen their force, these organizations try to expand their membership by providing various protection measures, which later enhance the members' organizational loyalty.

\section{Financial capability}

To conduct its action, all movements surely need some fund; hence, they will put an utmost effort to find some ways to access some financial sources. Likewise, these street vendors organizations collect their fund from several sources, such as collecting routine and non-routine membership fees, running cooperative, and trying to access financial assistance from the government. Non-routine membership fee is generally collected if they want to conduct some collective activities, i.e., protest to resist relocation; while routine membership fee varies from IDR 60,000 to IDR 300,000 per month and is spent for social fund, coordination fee, and organization's operational management.

Cooperatives become a source of funds through management of savings and loan. These savings and loans are obtained from the members and banking institutions. Cooperatives gain profits from the difference between deposits and loans taken by the members, or the difference in loan interest imposed by banks and cooperatives. In addition, some street vendors' organizations have started getting involved in procurement of goods for government agencies.

Moreover, government's financial assistance has only been accessible since 2011. In this case, the organizations attempt to build communication with the government to access the fund. Their success in accessing the financial assistance obviously depend on the committee members' capability in communicating and negotiating with the government.

\section{Other physical facilities}

Other physical facilities include buildings (their basecamp), computer, printer, and many others. For their basecamps, the organizations utilize the committee members' house or their business places. Their business places are considered more effective, as it is closer to the street vendors' daily lives. If they encounter some problems, they can immediately gather and discuss the issues.

Three resources (physical, non-physical, and financial) determine the power of the organizations. The more powerful their resources are, the stronger their bargaining positions against the government shall be; and vice versa. Using their bargaining power, the organizations can decide with whom they will affiliate themselves. The organizations with stronger bargaining positions usually manage themselves more independently and seldom ask for some favors from other parties. While the organizations with lower bargaining positions against the municipal government usually affiliate themselves with other civic organizations or larger street vendors' organizations. Such conditions 
divide the affiliation of street vendors' organization into four types: local organization; organization affiliated with civic organization; local organization affiliated with regional organization; and local organization affiliated with national organization.

\section{External consolidation: Establishing coalition}

Street vendors' organizations foster their relationships with various parties to help sustain their business or fight for their interests. Based on such relationship, three forms of coalition can be identified, namely political coalitions, political-economic, and economic coalitions. Political coalitions are built between street vendors and NGOs, university students, social activists, academics, institute of legal assistance (LBH), and mass media. The coalitions aim to bring recognition toward street vendors, as well as to grant them some shares of public spaces and to listen to their aspirations. These coalitions can be factually seen during organizations' protests with the help from NGOs and university students, or during the negotiation process with municipal government.

Political-economic coalitions are established between the street vendors, civic organizations, and some agents of municipal government. It is called 'political-economy', because the street vendors cooperate with other parties in order to obtain permission to trade within public spaces and to gain early information about government policies (control policy, empowerment programs, and many others); while civic organizations and government's agents gain economic benefits in the form of monthly cash deposit.

Moreover, economic coalitions are carried out by the street vendors with shop owners, goods suppliers, producers, banking institutions, and buyers; however, the coalition between the street vendors and the public has not been formed. There is no political interest involving their major goal to gain acknowledgement as the traders in informal sectors. With regards to coalition with public, some efforts towards that direction have begun to be carried out by trying to attract public sympathy, so that the public will be in favor of the interests of street vendors. The efforts are carried out through by disseminating some news about reorganization of street vendors and their social activities, such as painting city's sidewalks and giving donations to disaster-affected communities.

Based on the three types of coalition, within the street vendors' movement, there seems to be some people who obtain economic and political benefits from it. In addition, there are also free riders, referring to those who do not participate in the struggle yet taking benefits from the movement. These free riders can easily be identified during relocation process, in which the number of street vendors usually swells due to the emergence of "impromptu" street vendors. In addition, in some relocation sites, impromptu street vendors usually appear to replace the relocated street vendors who are unable or unwilling to rent a stall. They also appear in the original place after the relocation takes place. After relocation occurs, the streets are generally free from street vendors for several months. Then some 'wild' (non-member of any organizations) street vendors will emerge and if they are left unchecked, more of them will appear.

The organizations admit their difficulties in overcoming these "wild" street vendors. If there are few of them, the organizations usually visit them to prohibit them from selling in the location. However, this method is ineffective, because they will insist to stay, and their presence will trigger local thugs and some Satpol PP officers to request some financial retributions. Some street vendors organizations will invite these "wild" street vendors to become members of their organizations in exchange for protection or a stall in the relocation site (if there is a vacancy). However, if the number of 'wild' street vendors is too large, the organization seek government protection in the form of reorganization measures against these street vendors. This phenomenon shows that street vendors are heterogeneous groups based on socioeconomic characteristics and affiliations with other organizations.

\section{Outcomes of street vendor movement}

In general, the street vendors' movement managed to weaken the control and relocation policies of Bandung municipal government. Until now, street vendors can be easily found in public places, 
such as Cicadas street, Tegallega, $\mathrm{ABC}$ street, and many others. It shows that the policies have been inefficient to eliminate street vendors in public places. Likewise, relocation policy also has not been able to move street vendors from public places to the relocation sites. Restructuring and training policies for street vendors has yet to show optimal results, despite being hailed as a breakthrough. Provisions regarding street vendor's zones have not been implemented consistently, even though they are reinforced by fines against the customers at the red and yellow zone. When this study was carried out, there were still street vendors in both zones.

To conclude, does the PKL movement succeed in influencing municipal government policies? The success of social movements in influencing government policies can be examined from five aspects, namely the opening of access, response for the agenda, policy response, policy outcomes, and policy impacts(Porta\& Diani 1999). Therefore, the movement in Bandung has fulfilled the first three criteria. In the aspect of open access, the street vendor movement succeeded in making the municipal government of Bandung to willingly listen to the demands of street vendors' organizations, as shown by the case of street vendors' relocation at X street, Sumurbandung. The government agreed to relocate them to a shopping center building. In the aspect of response, the demands of street vendors for government to formulate policies that accommodate their interests became the political agenda of the government through revisions of the provisions regarding fines against customers and discussions about the relocation sites for street vendors. In the aspect of policy response, Regional Regulation No. 4 of 2011 concerning the Arrangement and Training of the Street Vendors reflects the success of the movement. The regulation signals that the movement successfully produces new policies which manifest the demands of the movement. Although some materials within the regulation are still questionable, yet the recognition of street vendors as a part of the informal economy is considered a victory.

Unfortunately, for the aspect of outcomes, the implementation of the regulation which emphasizes training and empowerment for the street vendors has not been optimized until now. It indicates by the absence of a sustainable relocation program. As a result, the street vendor movement has yet to subside.

\section{Street vendor movement as a social movement?}

The resistance attempt which is carried out by the street vendors started individually, through trialsand-errors, and uncoordinated. It began from gossiping, grumbling, pretending to be obedient, bribing, and so forth. Through these experiences, the street vendors determine the most effective ways to fight against the government policies. They began to build their strength by uniting themselves under some formal or informal organizations, so that the resistance turned into a collective resistance with increasingly diverse forms.

Variation of the movements indicate that the movements of urban communities are increasingly diverse. Resistance, which initially characterizes a movement, shifts into negotiation and cooperation, so that social movements are not aimed at gaining power position (permanent power position), but as bargaining tools to influence decision makers to provide some solutions which are beneficial for them (Wilson 1973). This posit is strengthen by a finding from Pambudi which stated that social movement also develops toward cooperative strategies (Pambudi 2010). Moreover, some street vendor movements have tried to compete within formal political channels by nominating some candidates as legislators.

In addition, the street vendors movement develops dynamically in accordance with the opportunities and contexts. If the municipal government enforces a harsh law on them, they will response through some physical fights. On the contrary, if the government enforces soft law, they will be softened, and more opportunities related to policy-making and access to municipal government shall be available. Accommodative policies, such as empowerment programs, from the government shall be responded by the street vendors through negotiation and cooperation in order to gain themselves some opportunities to access the programs. Moreover, access to the government will influence how the street vendors shape their struggle. If they have either direct or indirect (through intermediaries like organizations, academic institutions, and social activists, etc.) access to the government, they will be more likely to choose negotiation and corporation. 
The choice of resistance form is also influenced by Sundanese cultural factors. In general, Sundanese culture tends to maintain harmony, concordance, and peace, so that negotiation and cooperation are more favored by the street vendors in Bandung. The values are found in some proverbs like 'herang caina beunang laukna' (fish can maintain water purity; if the water stays pure, the fish can be caught) and 'ulah nyieun pucuk ti girang' (do not seek disorder or cause a scene). These values are unwittingly embedded within Sundanese people, including the street vendors. As a result, resistance methods like massive protest are only taken when the negotiations reach stalemate.

Understanding these cultural values is important, because mobilization is studied and rooted in various traditions and cultures. Community values and norms make collective actions difficult to understand, unless one understands about the values and norms. Not only that individual behavior can easily be monitored within his/her communities, but also because a solid community possesses some negative and positive on rules and social sanctions (McAdam et al. 1997).

Street vendor movement can be considered both old and new social movements. It is considered old social movement because the street movement has economic and ideological goals to maintain their business under the argument that the street vendors belong to urban poor groups. These characters are relevant to the old social movements, but their cause has been promoted to a broader context and cross social-class, such as human rights issues which involve people from various professional background (i.e. NGOs, press activists, university students, academics, legal activists, and social activists). The involvement of people across social categories, like gender, education, occupation, and class, is similar to the characteristics of a new social movement whose participants generally come from new middle class (Pichardo 1997). Those who belong to this group generally do not bound by motives of corporate profits and not relying on the corporate world for their survival. They generally work in sectors that are heavily dependent on state expenditure, such as academics, artists, agents of Christian services, and generally well-educated.

Participants in the street vendor movement are only limited to actors who are already accustomed to inducing a social movement, such as NGOs, social activists, and students; however, public sympathy is generally difficult to obtain, particularly from road users and communities around business locations due to their differences in defining public places. The general public defines public place as a place for social activity; while the street vendors define it as an economic resource. In addition, most road users consider street vendors generally troublesome. As a result, the issues of street vendors can only become the vendors' issues and unable to become a social issue. Thus, the difference between the street vendor movement and the social movement can be found within the movement ideology. The ideology of the street vendor movement is basically economic-based to earn a living; while social movements are usually based in common interests.

The inability of the street vendor movement to make their issues become a social issue has distinguished the movement from social movements like teacher movement in Oaxaca, Mexico in 2006. The teacher's national strike movement initially demanded better education and better wages. However, after the government repressed the protesters harshly, the movement turned into a popular movement to demand direct democracy and to reject the established political structure which was perceived as corrupt and repressive. This movement did not only involve activists and leaders of social movements, but also the general public who usually never participated in any demonstrations (Adler 2012). Therefore, can the street vendor movement be called a social movement? We conclude that they ae unable to be called as social movement. The street vendor movement do not qualify as resistance politics, which occur when general public joins hands with more influential community groups to mobilize forces in order to fight elites, authorities, and other opposing parties (Tarrow 1998).

\section{Conclusion}

The street vendor movement to fight for its place of business is carried out in several ways. First, unifying their own forces by forming the collective identities under the values of 'Kudu sapapait samamanis, sabagja cilaka' and 'Silih Asah, Silih Asih and Sutan Asuh,' which signify that they 
should look after and love each other as fellow street vendors. These values are maintained by street vendor organizations through informal activities, political stance during elections (general election/governor/mayor), and patron-client relations between the leaders and members to establish fun relationships between the members. Second, establishing network with various parties to help with the street vendor's struggle. Hence, three types of coalitions are established, including political coalition, economic-political coalition, and economic coalition.

The success of the street movement is determined by their abilities to manage human resources, finance, and other physical resources within the organizations. The greater resources owned by the organizations, the stronger their bargaining power will be. In addition, the street vendor movement is also driven by opportunities which are available at both national and local levels. National opportunities are related to political changes accompanying the change from New Order regime to post-New Order regime, which provided broader opportunities and political space to initiate, organize, and strengthen the street vendor movement. Whereas local opportunities are related to changes in policies and attitude of municipal government in implementing policies toward the street vendors. The changing paradigm from control policy to reorganizing and training has made the forms of PKL movements increasingly varied, not only prioritizing resistance actions, but also leading to cooperation. The organizations are not only in the form of association/foundations, but also in the form of cooperatives to access soft loans from banks.

Another factor helps determine the success of street vendor movement was the ability of street vendors to frame issues in order to justify their trade in public places. These issues are also used to counter the meaning of public places as interpreted by the government. In this case, the street vendors voice the issues of unjust policies, human rights, and marginalization of the street vendors by the municipal government. However, these issues have not been able to encourage public participation in street vendor movement, because the movement ideology evolves around economic ideology to earn a living; while ideology in social movements is usually based on a common interest. Hence, the movement ideology contradicts public interest in the use of public places. As a result, the street vendor movement cannot be considered as a social movement.

\section{References}

Adler M (2012) Collective identity formation and collective action framing in a Mexican: Movement of movement. A Journal For and About Social Movement 4 (1):287-315.

Aisyah U (2012) Pedagang Kaki Lima membandel di Jawa Timur. Jurnal Masyarakat, Kebudayaan dan Politik 25 (1):47-55.

Alisjahbana (2006) Marginalisasi Sektor Informal Perkotaan. Surabaya: ITS Press.

Edwards \& McCarthy dalam Snow A (2004). The Blackwell Companion to Social Movement. United Kingdom: Blackwell Publishing.

Gibbings SL (2011) Unseen Powers: Transparency and Conspiracy in a Street Vendor Relocation in Yogyakarta, Indonesia. ProQuest Dissertations and Theses.

Hanser A (2016) Street politics: Street vendors and urban governance in China. China Quarterly. https://doi.org/10.1017/S0305741016000278.

Hermanto D (2011) Gerakan sosial Pedagang Kaki Lima (Studi tentang hegemoni pada Pedagang Kaki Lima di Pasar Bambu Kuning Kota Bandar Lampung. Humanus X (1).

McAdam D, McCarthy JD, \& Zald MN (1996) Comparative Perspectives on Social Movement: Political Opportunities, Mobilizing Structures, and Cultural Framings. New York: Cambridge University Press, UK.

McAdam D, Tarrow S, \& Tilly C (1997) Toward and Integrated Perspective on Social Movements and Revolution. In: Comparative Politics: Rationality, Culture, and Structure (pp. 142-173). Cambridge: Cambridge University Press. 
Mustafa AA (2008) Model Transformasi Sosial Sektor Informal Sejarah, Teori dan Praksis Pedagang Kaki Lima. Malang: In-Trans Publishing.

Opp KD (2009) Theories of Political Protest and Social Movements: A Multidisciplinary Introduction, Critique, and Synthesis. London: Routledge.

Pambudi HS (2010) Masyarakat sipil dan dinamika politik: Studi terhadap gerakan masyarakat sipil di Yogyakarta 1998-2004. Program Pascasarjana Institut Pertanian Bogor.

Pichardo NA (1997) New social movements: A critical re-view. Annual Review Sociology 23:441.

Porta DD \& Diani M (1999) Social Movements: An Introduction. Oxford: Blackwell Publishing.

Siswono E (2009) Resistensi dan Akomodasi : Suatu Kajian Tentang Hubungan-Hubungan Kekuasaan Pada Pedagang Kaki-Lima (PKL), Preman dan Aparat di Depok, Jawa Barat. Jakarta.

Snow A, Zuhrer LA, Ekl S, \& Ekland-olson S (1980) Social network and social movement: A microstructural approach to differential recruitment. American Sociological Review 45:787801.

Tarrow S (1998) Power in Movement. Cambridge: University Press.

Turner S \& Schoenberger L (2012) Street vendor livelihoods and everyday politics in Hanoi, Vietnam: The seeds of a diverse economy? Urban Studies. https://doi.org/10.1177/0042098011408934.

Wilson J (1973) Introduction to Social Movements. NewYork: Basic Books,Inc. 